\title{
ГРАМАТИЧНІ ТА ПРАГМАСЕМАНТИЧНІ ОСОБЛИВОСТІ СПОНУКАЛЬНИХ ВИСЛОВЛЮВАНЬ В АНГЛІЙСЬКОМОВНОМУ ПУБЛІЦИСТИЧНОМУ ДИСКУРСІ (на матеріалі заголовків статей онлайн версії The Guardian)
}

\begin{abstract}
Стаття присвячена встановленню граматичних та прагмасемантичних особливостей спонукальних висловлювань у заголовках англійськомовного публічистичного дискурсу на матеріалі статей онлайн версії періодичного видання The Guardian. Окреслено місие та статус спонукальності в колі дискурсивних досліджень, уточнено термінологічну базу та запропоновано визначення спонукання як об'єктного поля лінгвістичного дискурсу. 3'ясовано, що непрямі спонукальні мовленнєві акти значно переважають над прямими не тільки чисельно, але й демонструють більшу варіативність інвентарю способів свого вираження в мовленні. Аналіз прагматичних особливостей матеріалу дослідження дозволив виділити низку мовленнєвих актів, серед яких зокрема наказ, порада, прохання, побажання, запрочення, заборона, дозвіл, виправдання, інструкція, підбурювання, загроза.
\end{abstract}

Ключові слова: публічистичний дискурс, семантика, прагматика, імператив, спонукальне висловлювання, прямий / непрямий спонукальний акт.

\section{1. Вступні зауваження}

Розвиток сучасного мовознавства засвідчує, що поглиблене вивчення мови як найважливішого засобу спілкування неможливе без залучення до аналізу комунікативно-прагматичного аспекту іiї функціонування (Бацевич 12-13). Будьяка мовна інтеракція (усна або письмова) як інструмент передачі інформації передбачає досягнення перцептивної мети між комунікантами. Саме тому природним $є$ підвищений інтерес з боку мовознавців до проблем комунікації та мовленнєвої поведінки комунікантів.

Виконуючи певну інтеракцію, комунікант має на меті не тільки інформувати реципієнта, але і продемонструвати своє ставлення до блоку інформації, який передається, певним чином вплинути на об' єкт(и) комунікативного акту (Poole 73). Саме тому реалізація впливової функції мови привертає значну увагу не тільки мовознавців (Rodríguez-Vergara), але і представників суміжних наук (O’Keeffe), таким чином формуючи міждисциплінарне дискурсивне поле наукових досліджень. Окрему увагу привертає й спонукальна функція мови (Бацевич 28), адже спонукання як мовленнєвий акт, при якому діяльність одного комуніканта вербально регулюється іншим, відіграє значну роль у процесі спілкування і керує взаємовідносинами між комунікантами (Potsdam, Edmiston).

У свою чергу комунікативно-прагматичний напрям лінгвістичних досліджень (Загнітко), який базується на урахуванні соціальних, міжособистісних, ін- 
дивідуально-психологічних, культурологічних, когнітивних, експертизних (від англ. expertise «special skills or knowledge in a particular subject, that you learn by experience or training» 'спеціальні навички або знання в певній царині, які отримані через досвід або навчання') характеристик учасників комунікативного акту в конкретних умовах його перебігу, передбачає дослідження спонукальної функції мови крізь призму їхньої ролі для досягнення перцептивної мети.

Таким чином, актуальність даної наукової розвідки обумовлена потребою більш детального аналізу граматичних та прагмасемантичних особливостей спонукальних висловлювань в англійськомовному публіцистичному дискурсі, що дозволить укласти інвентар спонукальних мовленнєвих актів та окреслити комунікативні стратегії, які використовуються мовцями для досягнення комунікативних інтенцій.

Об'сктом виступають спонукальні висловлювання англійської мови, дібрані методом суцільної вибірки із заголовків статей онлайн версії періодичного видання The Guardian.

Предметом наукової розвідки виступають граматичні та прагмасемантичні особливості спонукальних висловлювань в заголовках англійськомовного публіцистичного дискурсу.

Мета роботи полягає у визначенні специфіки граматичних та прагмасемантичних особливостей спонукальних висловлювань та інвентаризації способів та засобів їхнього вираження у мові заголовків в англійськомовному публіцистичному дискурсі.

Для досягнення мети, в роботі ставляться такі основні завдання:

- уточнити сутність поняття «спонукальність» у прагматичному та семантичному аспекті;

- інвентаризувати засоби вираження спонукальності в заголовках у сучасному англійськомовному публіцистичному дискурсі;

- окреслити граматичні та прагмасемантичні особливості спонукальних висловлювань в рамках емпіричного корпусу дослідження.

Емпіричний корпус дослідження складається зі 150 одиниць, дібраних методом суцільної вибірки з сучасних англійськомовних публіцистичних джерел; одиницею дослідження виступає заголовок публіцистичної статті. Джерелом емпіричного матеріалу стали статті англійськомовного періодичного видання The Guardian, розміщені на його офіційній онлайн платформі (див. https://www.theguardian.com/international).

Мета та завдання, окреслені в роботі, а також специфіка об'єкта дослідження зумовили використання низки методів та прийомів лінгвістичного аналізу, серед яких зокрема метод суцільної вибірки, компонентний аналіз, синтаксичний аналіз, морфологічний аналіз, дискурс-аналіз, описовий метод та елементи кількісних підрахунків.

\section{2. Теоретичні засади дослідження}

У зв'язку зі зміною наукової парадигми та втратою провідної ролі структурної лінгвістики, в основі якої лежить розуміння мови як знакової системи 3 чітко виділеними структурними елементами та прагнення до опису мови (Шили- 
хина), особлива увага прикута до питань, пов’язаних з комунікацією, прагматичною ситуацією, фактором адресата тощо.

Теорія комунікації чітко диференціює терміни «комунікація» і «спілкування»: комунікація розуміється як обмін думками та інформацією у формі мовних або письмових сигналів, в той час як спілкування - це двоспрямований процес, який відбиває обмін думками, інформацією й емоційними переживаннями. Спілкування є актуалізацією комунікативної функції мови у різних прагматичних ситуаціях. У той час як за спілкуванням закріплюються характеристики міжособистісної взаємодії, за комунікацією закріплюється додаткове значення інформаційний обмін у суспільстві (Киселёва 11).

Категорія спонукальності є невід'ємним і суттєвим елементом комунікації. Дослідження категорії спонукальної - одне із найбільш динамічних напрямків сучасного мовознавства, про що свідчить низка наукових робіт за темою (Беляева; Большакова; Дрінко; Маркуляк; Неустроев; Han; Potsdam, Edmiston тощо). Наразі, дослідженню підлягали як комунікативно-прагматичні властивості спонукання (див. наприклад Сусов) так і структурні, семантичні та функційні особливості мовних засобів його вираження (див. наприклад Маслова).

Імператив, який розглядається як одна 3 найдавніших семантичних універсалій, представлений у всіх мовах, у всіх типах текстів і має глобальне значення в комунікації та людської діяльності. Як зазначає О. В. Вєльський, «спілкування немислимо без спонукання до дії. Люди безперервно звертаються один до одного iз різноманітними спонукальними фразами» (Вельский 83).

У сучасній лінгвістичній науці терміни «імперативність» і «спонукальність» нерідко використовуються синонімічно, про що свідчить зокрема думка В. С. Храковського та О. П. Володіна, які вважають, що імператив або спонукання - це повідомлення про бажання мовця, щоб адресат виконав певну дію, i спроба каузувати його виконання адресатом (Храковский, Володин). Втім, слід чітко розмежовувати категорії каузальності, каузації та спонукальності, які є певною мірою суміжними, але не тотожними (Залужна 13-14).

Спонукання, яке також у наукових джерелах за темою називають імперативом та волютативом, - це універсальне явище, яке характерне для усіх мов світу, якими користується людина; різниця виникає лише в інвентарі засобів його вираження в різних мовах. У даній роботі, в рамках обраного підходу до вивчення окресленого емпіричного матеріалу дослідження, за робоче обрано наступне визначення: спонукання - це вербальне вираження інтенцій комуніканта, спрямоване на пряме або опосередковане заохочення реципієнта до дії для досягнення запланованої комунікантом перцептивної мети.

Категорія спонукальності розглядається сучасною лінгвістичною наукою передусім як функційно-семантична категорія 3 польовим принципом побудови різнорівневих мовних одиниць спонукальної семантики (Дрінко). У порівнянні зі спонуканням, яке виражає бажання мовця впливати на слухача або третю особу з метою зміни ситуації, термін «спонукальність», як правило, має ширше значення: це властивість людей та інших явищ об'єктивної дійсності каузувати зміни навколишньої дійсності (Беляева). 
Сучасний стан лінгвістичної науки демонструє, що одним із найбільш продуктивних підходів до вивчення спонукальності є іiі дослідження в рамках різних типів дискурсу (див. наприклад, роботи Иванова, Рыболовлев або Pang, Wu). Починаючи з перших досліджень у галузі дискурсології (Harris), такий підхід виявився продуктивним не тільки для суто лінгвістичного вивчення мовних явищ, але і для викладання іноземних мов і теорії та практики перекладу (Rodríguez-Vergara).

Проте коло питань, пов'язаних із функціонуванням спонукання в сучасному англійськомовному публіцистичному дискурсі та специфікою засобів його вираження, на нашу думку, потребує більш детального вивчення. Зокрема, проблема позамовної обумовленості спонукання (підстави, які спричиняють конкретну інтенцію мовця та умови іiі застосування), причини виникнення додаткових прагматичних ознак, які нашаровуються на основний зміст спонукання, особливості мовленнєвої тактики комунікантів у конкретних спонукальних ситуаціях все ще не знайшли належної уваги лінгвістів.

Сучасні дискурсивні дослідження спонукальних конструкцій відзначають їхню обов'язкову спрямованість на адресата, діалогічність і спрямованість на програмування поведінки реципієнта (Киселёва). Із категорією спонукальності, іiі імпліцитними та експліцитними способами вираження безсумнівно пов'язані мовні особливості реалізації поняття спонукання (Басок). Вважаючи правомірним віднесення категорії спонукальної до комунікативно-семантичних, О. І. Бєляєва виходить із того, що реалізація категорії здійснюється за допомогою ієрархічно організованих і взаємодіючих комунікативних, прагматичних і власне лінгвістичних складових (Беляева).

У контексті лінгвістики тексту спонукальність розглядається як категорія, яка визначає типовий для директивного тексту набір мовних засобів (Неустроев 33). Різні морфологічні, лексико-граматичні, лексичні та синтаксичні засоби актуалізують категорію спонукальності, корелюючи з певними типами та підтипами директивно-регулятивних текстів. Функційно-стилістична приналежність і комунікативно-прагматична спрямованість тексту є детермінантними у механізмі відбору мовних одиниць та їхнього функціонування в директивно-регулятивних текстах (Маслова 6).

Із прагмалінгвістичної точки зору спонукальність розглядається як комунікативне значення або іллокутивна сила, конкретний зміст якої складається з вихідної ситуації, мовного акту, аудитивного акту, практичного акту та результуючої ситуації (Маркуляк, 125-126). Дослідники відзначають, що теорія мовних актів надає адекватний апарат для опису вербальних способів вираження спонукальності (Martin, Rose). Мовні акти, спрямовані на зміну поведінки та стану співрозмовника, є спонукальними, директивними або регулятивними актами. Спонукальність у них являє собою частину прагматичного значення (Иванова, Рыболовлев).

Специфіка спонукальності полягає в тому, що саме базове значення цієї категорії піддається об'єктивній диференціації залежно від сили інтенції; означувана сила варіюється та проявляється в категоричності, нейтральності або 
м’якості спонукання. Л. О. Кісєльова відзначає, що мовні засоби, закріплені за якоюсь однією функцією, утворюють особливу ієрархічну систему, або мовне поле. За ії словами, «спонукальне поле поділяється на такі підсистеми, як поле категоричного спонукання, поле пом'якшеного спонукання та поле нейтрального спонукання» (Киселёва, 57). На думку дослідниці, поле категоричного спонукання складається з таких підсистем, як поле наказу, поле команди, поле вимоги, поле заборони; поле пом'якшеного спонукання складається з поля прохання та поля благання; поле нейтрального спонукання містить пропозиції та поле побажання.

Категорія спонукання має трирівневу структуру, до якої входять план змісту, план вираження та план трансляції. Виокремлюють три основні прагматичні типи директивних мовленнєвих актів: прескриптиви (пріоритетність мовця), прескриптиви (пріоритетність адресата) та сугестиви (пріоритетність мовця і бенефактивність дії для адресата) (Шевченко).

Лінгвістична складова категорії спонукальної представлена сукупністю різнорівневих мовних засобів, які виражають спонукальні значення, і організовані за принципом функційно-семантичного поля. Категоріальною підставою спонукальності виступає категоріальний сенс спонукання - загально-категорійне значення, яке складається з набору значень окремих комунікативно-семантичних груп, кожна 3 яких має комунікативний зміст, обумовлений комунікативною спонукальною метою. Категоріальний принцип системної організації $є$ ієрархічним, що репрезентує взаємодію комунікативних, прагматичних, семантичних і власне мовних чинників (Беляева, 8-10).

Крім того, розрізняють позитивне та негативне спонукання: до позитивного зараховують вимогу та / або наказ, а до негативного - заборону та / або попередження.

Засоби вираження категорії спонукальності поділяють на експліцитні та імпліцитні. До експліцитних відносять дієслівні імперативні речення з ввічливими та різкими відтінками спонукання; кінцеві формативи, такі як will you, will not you, shall we; вживанням початкового емфатичного дієслова $d o$; бездієслівні спонукальні речення. До кола імпліцитних засобів вираження категорії спонукальності зараховують питання з допоміжними дієсловами will, shall, should, would, які виражають м'яке, ввічливе прохання; розділові питання; модальні дієслова can, could, may, must; дієслова у майбутньому часі; розповідні речення, які використовуються в імпліцитних формах спонукання до дії (Басок).

Отже, функційно-семантичне поле категорії спонукальності містить різні семантичні відтінки, які, у свою чергу, виражаються за допомогою різноманітних засобів мовлення.

\section{3. Мовні засоби вираження спонукальності в заголовках статей англійськомовного публіцистичного дискурсу}

Результати аналізу емпіричного корпусу дослідження демонструють, що непрямі спонукальні мовленнєві акти характеризуються найбільшою продуктивністю і становлять 71,3\% (107 од.) емпіричної бази дослідження (напр. Hello! Would you like a free book? 'Привіт! Ви хотіли б безкоштовну книгу?). Прямі спо- 
нукальні висловлювання виявилися менш продуктивними і склали $28,7 \%$ емпіричного корпусу (43 од.) (напр. I am an ER doctor. Please take coronavirus seriously 'Я доктор швидкої допомоги. Будь ласка, сприймайте коронавірус серйозно').

3.1. На окрему увагу заслуговує той факт, що непрямі спонукальні мовленнєві акти домінують не тільки чисельно в емпіричному корпусі дослідження, але і демонструють більшу варіативність інвентарю способів свого вираження в мовленні:

- питальні речення різних типів, напр. Can we please stop talking about Adel's $\underline{b o d y}$ ? ‘Чи не могли б ми, будь ласка, припинити обговорювати тіло Адель?'; Why Don't You Just Die! review - ingenious drama with hints of Tarantino 'Чому 6 тобі просто не померти?' огляд - майстерна драма з натяком на Тарантіно;

- еліптичні (бездієслівні) реченнями, напр. No More Boys and Girls: Can Kids Go Gender Free? review - reasons to start treating children equally 'Більше ніяких хлопців та дівчат: чи зможуть дітлахи жити вільними від статі? огляд - причини почати поводитися 3 дітьми однаково';

- сталі вирази з інгерентною семантикою спонукальності, напр. Ben Kingsley: 'Do you mind if I finish what I was saying?' 'Бен Кнігслі: «Ви не заперечуєте, якщо я закінчу те, про що я говорив?»';

- дієслово to suggest та конструкції з ним, напр. How do уоu acquire and keep rich friends? I suggest dinner 'Як завести та зберегти багатих друзів? Я пропоную вечерю';

- конструкція Complex Object із дієсловом to want, напр. We don't want billionaires' charity. We want them to pay their taxes 'Ми не хочемо благодійності від мільярдерів. Ми хочемо, щоб вони платили свої податки';

- умовний спосіб в додатках після дієслова to wish, напр. I wish more people would read. Damon Runyon's short stories 'Я б хотів, щоб більше людей читали. Оповідання Деймона Руньйона';

- каузативні дієслова to make, to get, to help, to have тощо, напр. Strategy board games to help you escape Covid ' Стратегічні настільні ігри, які допоможуть втекти від ковіду';

- пасивна конструкція з модальною семантикою to be allowed, напр. UK lockdown rules: what you are allowed to do from Monday 'Правила карантину в Великобританії: що дозволено робити з понеділка'.

3.2. Найбільш продуктивними засобами вираження прямих спонукальних мовленнєвих актів виявилися:

- спонукальні конструкції з дієсловом у формі синтетичного імператива, напр. Help us to stop the war 'Допоможіть нам зупинити війну';

- спонукальні конструкції з дієсловом у формі аналітичного імператива, напр. Let's move to Rotterdam: Eurovision's new home 'Давайте поїдемо до Роттердаму: нового дому Євробачення';

- конструкції з модальними дієсловами зі спонукальною семантикою should, need, must та їхніми еквівалентами to have to, to be necessary тощо, напр. We can't rely on the media to call the election fairly. Here's what we need to do about it 'Ми не можемо розраховувати на 3MI, щоб вони називали вибори чесними. Ось що ми 
маємо зробити'; Children over 12 should wear face masks to combat Covid, says $W H O$ 'Діти старші 12 років повинні носити маски, щоб побороти ковід, говорить BOO3'.

4. Прагматика спонукальних мовленнєвих актів в заголовках статей англійськомовного публіцистичного дискурсу

Аналіз прагматичних особливостей емпіричної бази дослідження дозволив виокремити наступні типи спонукальних мовленнєвих актів:

- наказ, напр. Hobbies make us happier - so ignore the mockery, and enjoy 'Хобi роблять нас щасливішими - отже, ігноруйте насмішки і насолоджуйтесь';

- порада, напр. 'Focus on the things you can control': how to cope with radical uncertainty '«Сфокусуйтеся на речах, які Ви можете контролювати»: як впоратися з радикальною невпевненістю';

- прохання, напр. Help us test water quality across the US: is your water safe enough? 'Допоможіть нам протестувати якість води в США: а Ваша вода достатньо безпечна?';

- побажання, напр. 'There should be fines': east London shoppers on mask law '«Повинні бути штрафи»: покупці у східному Лондоні з приводу закону про маски';

- запрошення, напр. Can we have a conversation about Kamala Harris 's ideas? 'Ми можемо поговорити про ідеї Камаля Гарріса?';

- заборона, напр. No more 'nagging wives': how Oxford Dictionaries is cleaning up sexist language ‘Більше ніяких «діставучих дружин»: як Оксфордські словники підчищають мову сексизму';

- дозвіл, напр. Don't worry about 'rewriting history': it's literally what we historians do 'Не хвилюйтеся про «переписану історію»: це по суті те, що роблять історики';

- виправдання, напр. Don't blame us for UK's coronavirus spike, say young people 'Не звинувачуйте нас у новій хвилі коронавірусу, говорить молодь';

- інструкція, напр. Wanna get really high? Take a dab in the world of concentrates 'Хочеш дійсно кайфонути? Занурюйся у світ концентратів';

- підбурювання, напр. Let's seize this rare chance to abolish school exams and league tables 'Давайте схопимо цей рідкий шанс скасувати шкільні іспити та рейтинги';

- загроза, напр. Dr Crippen: Just don't try giving me the swine flu vaccine 'Доктор Кріппен: Навіть не намагайся дати мені вакцину від свинячого грипу’.

\section{5. Висновки}

5.1. Спонукальні висловлювання посідають чільне місце серед дискурсивних лінгвістичних досліджень і відзначаються високою продуктивністю. У рамках дослідження дискурсу категорії спонукальності та спонукання; каузальності, каузації та спонукальності $є$ певною мірою суміжними, але не тотожними.

5.2. Спонукання - це вербальне вираження інтенцій комуніканта, спрямоване на пряме або опосередковане заохочення реципієнта до дії для досягнення запланованої комунікантом перцептивної мети. 
5.3. Спонукальні мовленнєві акти поділяються на прямі та непрямі, останні в емпіричному корпусі дослідження переважають чисельно та демонструють більшу варіативність інструментарію вираження.

5.4. Прагматично-комунікативна складова спонукальних висловлювань демонструє значний інвентар спонукальних мовленнєвих актів, серед яких зокрема наказ, порада, прохання, побажання, запрошення, заборона, дозвіл, виправдання, інструкція, підбурювання, загроза.

5.5. Перспектива подальшого дослідження вбачається в розширенні емпіричної бази дослідження за рахунок залучення інших англійськомовних періодичних публіцистичних видань; у проведенні зіставного аналізу використання спонукальних конструкцій в заголовках статей у сучасному публіцистичному дискурсі в різних лінгвокультурах; в укладанні типології спонукальних висловлювань та типових смислів, які вони виражають в сучасному публіцистичному дискурсі.

\section{Література}

1. Басок В. А. Експліцитні та імпліцитні засоби відтворення комунікативної інтенції в українських перекладах англомовних маркетингових текстів. Науковий вісник Міжнародного гуманітарного університету. Сер. : Філологія. 2014. №9. С. 72-74.

2. Бацевич Ф. С. Основи комунікативної лінгвістики. К. : Академія, 2004. 344 с.

3. Беляева Е. И. Грамматика и прагматика побуждения: английский язык. Воронеж : Изд-во ВГУ, 1992. $168 \mathrm{c.}$

4. Большакова Т. М. Состав и функционирование прескрипций и прохибитивов в немецкоязычных текстах директивно-регулятивного типа (прагмалингвистический и социокультурный аспекты): автореф. дис. ... канд. филол. наук. СПб., 2005. 23 с.

5. Вельский А. В. Побудительная речь. Учен. зап. Моск. пед. ин-та иностр. яз. им. М. Тореза. M., 1953. T. VI. C. 81-147.

6. Дрінко Г.Г. Спонукальні конструкції в англійській та українських мовах: автореф. дис. ... канд. філол. наук. Донецьк, 2005. 21 с.

7. Загнітко А. П. Комунікативно-прагматичні аспекти сучасного політичного газетного дискурсу. Культура народов Причерноморья. 2007. № 110, Т. 1. 190-193.

8. Залужна О. О. Лексико-стилістичні та структурно-синтаксичні особливості привативних дієслів в англійській та українській мовах : монографія (Типологічні, зіставні, діахронічні дослідження). Вінниця: ТОВ «Нілан- ЛТД», 2019. 314 с.

9. Иванова И. В., Рыболовлев Н. Р. Роль категории повелительности в организации директивного текста (на материале польского, русского и немецкого языков). Функциональнотипологические аспекты анализа императива. М., 1990. Ч. 2. С. 31-35.

10. Киселёва Л. А. Язык как средство воздействия. Л. : Ленингр. гос. пед. ин-т им. А. И. Герцена, 1971. 59 с.

11. Маркуляк Л. В. Оптативні відношення в системі спонукальних конструкцій. Актуальні проблеми філологї та перекладознавства. 2015. №. 9. С. 117-121.

12. Маслова А. Ю. Коммуникативно-семантическая категория побудительности и ее реализация в славянских языках (на материале сербского и болгарского языков в сопоставлении с русским) : автореф. дис. ... д-ра филол. наук. М., 2009. 26 с.

13. Неустроев К. С. Способы выражения побуждения и воздействия (на материале современного английского языка) : автореф. дис. ... канд. филол. наук. Ростов н/Д, 2008. 21 с.

14. Сусов И. П. Побудительность: деятельностьно-коммуникативное и функционально-семантическое представление. Императив в разноструктурных языках. Л., 1988. С. 125-127. 
15. Храковский В. С., Володин А. П. Семантика и типология императива: русский императив. М.: УРСС, 2001. $272 \mathrm{c.}$

16. Шевченко I. С. Мовленнєвий акт і дискурс в когнітивно-прагматичному та історичному ракурсі. Переклад у наукових дослідженнях представників Харківської школи : кол. монографія. Вінниця : Нова книга, 2013. С. 117-134.

17. Шилихина К. М. Вербальные способы модификации поведения и эмоционально-психологического состояния собеседника в российской и американской коммуникативных культуpax : автореф. дис. ... канд. филол. наук. Воронеж, 1999. 23 с.

18. Han Chung-hye The Structure and Interpretation of Imperatives: Mood and Force in Universal Grammar. IRCS Technical Reports Series. 1998. 74. 237 p.

19. Harris Z. Discourse Analysis. Language. 1952. 28(1), Pp. 1-30.

20. Martin J. R., Rose D. Working with Discourse: Meaning Beyond the Clause (2nd ed.). London: Continuum, 2007. 368 p.

21. Pang H., Wu S. Critical Instance Analysis of News English Discourse. English Language Teaching. CCSE. 2009. Vol. 2, №2. Pp. 148-151.

22. Poole D. Discourse Analysis and Applied Linguistics. The Oxford Handbook of Applied Linguistics (R. B. Kaplan (ed.)). Oxford: Oxford University Press, 2010. Pp. 73-84.

23. Potsdam E., Edmiston D. Imperatives. Oxford : Oxford University Press, 2015. doi: 10.1093/OBO/9780199772810-0107

24. O'Keeffe A. Media and Discourse Analysis. The Routledge Handbook of Discourse Analysis. Chapter: Institutional Applications. Oxon : N.Y. : Routledge, 2012. Pp. 104-119.

25. Rodríguez-Vergara D. The Importance of Discourse Studies in Linguistics, Language Teaching and Translation. US-China Foreign Language. 2018, Vol. 16, No. 6. Pp. 297-310. doi:10.17265/1539-8080/2018.06.001

\section{References}

1. Basok, V. A. Eksplitsytni ta implitsytni zasoby vidtvorennya komunikatyvnoyi intentsiyi v ukrayins'kykh perekladakh anhlomovnykh marketynhovykh tekstiv (Explicit and Implicit Means of Creating Communicative Intentions in Ukrainian Translations of English Marketing Texts). Naukovyy visnyk Mizhnarodnoho humanitarnoho universytetu. Ser. : Filolohiya. (Scientific Bulletin of International Humanities University. Series: Philology). №9 (2014): 72-74. Print.

2. Batsevych, F. S. Osnovy komunikatyvnoyi linhvistyky (Foundations of Communicative Linguistics). Kyiv : Akademiya, 2004. Print.

3. Belyaeva, E. I. Grammatika i pragmatika pobuzhdeniya: angliyskiy yazyik (Grammar and Pragmatics of Inducement: the English Language). Voronezh : Izd-vo VGU, 1992. Print.

4. Bolshakova, T. M. Sostav i funktsionirovanie preskriptsiy i prohibitivov v nemetskoyazyichnyih tekstah direktivno-regulyativnogo tipa (pragmalingvisticheskiy i sotsiokulturnyiy aspektyi) (Content and Functions of Prescriptives and Prohibitives in German Texts of Directive Regulatory Type (Pragmatic and Sociocultural Aspects)). Diss. Russian State Pedagogical U, 2005. Abstract. Print.

5. Velskiy, A. V. Pobuditelnaya rech (Inducement Speech). Uchen. zap. Mosk. ped. in-ta inostr. yaz. im. M. Toreza (Sceintific Notes of Moscow Pedagogical University of Foreign Languages by M. Torez). 6 (1953): 81-147. Print.

6. Drinko, H. Sponukalni konstruktsii v anhliiskii ta ukrainskii movakh (Inducement Constructions in the English and Ukrainian languages). Diss. Donetsk National U, 2005. Abstract. Print.

7. Zahnitko, A. P. Komunikatyvno-prahmatychni aspekty suchasnoho politychnoho hazetnoho dyskursu (Communicative and Pragmatic Aspects of Modern Political Newspaper Discourse). Kul'tura narodov Prychernomor'ya (Culture of Prychernomor'ya Peoples). № 110. Vol. 1 (2007): 190-193. Print.

8. Zaluzhna, O. O. Leksyko-stylistychni ta strukturno-syntaksychni osoblyvosti pryvatyvnykh diyesliv v anhliys'kiy̆ ta ukrains'kiy movakh (Lexical, Stylistic, Structural, and Syntactic Pecu- 
liarities of Privative Verbs in English and Ukrainian). Vinnytsya: TOV «Nilan- LTD», 2019. Print.

9. Ivanova, I. V., \& Ryibolovlev, N. R. Rol kategorii povelitelnosti v organizatsii direktivnogo teksta (na materiale polskogo, rucckogo i nemetskogo yazyikov) (The Role of the Category of Imperative Mood in Directive Text Organisation (on the Basis of the Polish, Russian, and German Languages)). Funktsionalno-tipologicheskie aspektyi analiza imperativa (Functional and Typological Aspects of the Imperative Mood Analysis). Moscow, 1990. Part 2. 31-35. Print.

10. Kiselyova, L. A. Yazyik kak sredstvo vozdeystviya (Language as Means of Inducement). Leningrad : Leningr. Gos. Ped. Institute im. A. I. Gertsena, 1971. Print.

11. Markulyak, L. V. Optatyvni vidnoshennya v systemi sponukal'nykh konstruktsiy (Optative Relations in the System of Imperative Constructions). Aktual'ni problemy filolohiyi ta perekladoznavstva (Acute Issues of Philology and Translation) 9 (2015): 117-121. Print.

12. Maslova, A. Yu. Kommunikativno-semanticheskaya kategoriya pobuditelnosti i ee realizatsiya $\mathrm{v}$ slavyanskih yazyikah (na materiale serbskogo i bolgarskogo yazyikov v sopostavlenii s russkim) (Communicative and Semantic Category of Inducement and Its Realisation in Slavic Languages (Based on Serbian and Bulgarian Languages in Comparison with Russian)). Diss. St. Peterburg State U, 2009. Abstract. Print.

13. Neustroev, K. S. Sposobyi vyirazheniya pobuzhdeniya i vozdeystviya (na materiale sovremennogo angliyskogo yazyika) (Ways of Expressing Inducement and Influence (Based on Modern English Language)). Diss. Southern Federal U, 2008. Abstract. Print.

14. Susov, I. P. Pobuditelnost: deyatelnostno-kommunikativnoe i funktsionalno-semanticheskoe predstavlenie (Inducement: Action, Communicative, Functional, and Semantic View). Imperativ $v$ raznostrukturnyih yazyikah (Imperatives in the Languages of Different Systems). Leningrad: Nauka, 1988. 125-127. Print.

15. Hrakovskiy, V. S., \& Volodin, A. P. Semantika i tipologiya imperativa: russkiy imperative (Semantics and Typology of Imperatives: Russian Imperative). Moscow : URSS, 2001. 272. Print.

16. Shevchenko, I. S. Movlennyevyy akt i dyskurs v kohnityvno-prahmatychnomu ta istorychnomu rakursi (Speech Act and Discourse in Cognitive, Pragmatic, and Historical Aspects). Pereklad u naukovykh doslidzhennyakh predstavnykiv Kharkivs'koyi shkoly (Translation in Scholarly Researches by Representatives of Kharkiv School). Vinnytsya: Nova knyha, 2013. 117-134. Print.

17. Shilihina, K. M. Verbalnyie sposobyi modifikatsii povedeniya i emotsionalno-psihologicheskogo sostoyaniya sobesednika v rossiyskoy i amerikanskoy kommunikativnyih kulturah (Verbal Means of Modifications in Behaviour, Emotional and Psychological State of the Interlocutor in Russian and American Communicative Cultures). Diss. Voronezh State U, 1999. Abstract. Print.

18. Han Chung-hye The Structure and Interpretation of Imperatives: Mood and Force in Universal Grammar. Diss. U of Pennsylvania, 1998. Print.

19. Harris Z. Discourse Analysis. Language. 28(1) (1952): 1-30. Print.

20. Martin J. R., \& Rose D. Working with Discourse: Meaning Beyond the Clause (2nd ed.). London: Continuum, 2007. Print.

21. Pang H., \& Wu S. Critical Instance Analysis of News English Discourse. English Language Teaching. CCSE. 2/2 (2009) : 148-151. Print.

22. Poole D. Discourse Analysis and Applied Linguistics. The Oxford Handbook of Applied Linguistics (R. B. Kaplan (ed.)). Oxford: Oxford University Press, 2010. 73-84. Print.

23. Potsdam E., \& Edmiston D. Imperatives. Oxford: Oxford University Press, 2015. doi: 10.1093/OBO/9780199772810-0107

24. O'Keeffe A. Media and Discourse Analysis. The Routledge Handbook of Discourse Analysis. Chapter: Institutional Applications. Oxon : N.Y. : Routledge, 2012. 104-119. Print.

25. Rodríguez-Vergara D. The Importance of Discourse Studies in Linguistics, Language Teaching and Translation. US-China Foreign Language. 16/6 (2018): 297-310. doi:10.17265/15398080/2018.06.001 


\section{GRAMMATIC AND PRAGMASEMANTIC FEATURES OF INDUCEMENT UTTERANCES IN ENGLISH-SPEAKING MEDIA DISCOURSE (BASED ON HEADLINES IN THE GUARDIAN ON-LINE VERSION) \\ Olha Zaluzhna}

English Philology Department, Vasyl' Stus Donetsk National University, Vinnytsia, Ukraine Oleksandra Kholodiuk

English Philology Department, Vasyl' Stus Donetsk National University, Vinnytsia, Ukraine

Abstract

Background: The issue of the inducement utterances discourse analysis has remained topical for modern linguistic research for many years, the evidence of which are numerous theoretical and empiric studies. Yet, the scope of theoretical questions open for discussion and the variety of the discourse realm involved leave fruitful ground for further research. The present article offers an outline of grammatic and pragmasemantic peculiarities of inducement utterances used in headlines of the Guardian (its on-line based version).

Purpose: The purpose of the present research is to identify specific features of the inducement utterances grammatic and pragmasemantic features within the media discourse, establish the inventory of the language means used, and identify typical meanings expressed by the inducement speech acts singled out in the process of the research.

Results: The empiric database analysis allows to arrive at conclusion that inducement speech acts can be distributed into two groups: direct and indirect, the latter demonstrating quantitative dominance and being represented by significantly bigger inventory of language means of its expression. The insight into the pragmatic peculiarities of the language material studied makes it possible to single out the following speech acts which include but are not limited to order, advise, request, wish, invitation, prohibition, permission, excuse, instruction, incitement, threat.

Discussion: Inducement is the verbal expression of the communicant's intension(s) directed (directly or indirectly) at the recipient to encourage them to perform an action with the aim of achieving the communicant's perceptive goal. The strong preference for indirect inducement communicative acts can be predetermined by the fact that English-speaking language culture demonstrates inclination to expressing inducement with the help of non-direct language means. The inventory of speech acts, singled out during the research, indicates that the communicant's intentions vary greatly, and this variety in its turn allows to transmit the nuances of the communicative message so as to achieve the goal of the communication.

Key words: media discourse, semantics, pragmatics, imperatives, inducement utterance, direct / indirect inducement act.

Vitae

Olha Zaluzhna is a PhD in Philology, Associate Professor at English Philology Department at Vasyl' Stus Donetsk National University, Vinnytsia, Ukraine. Her areas of research include contrastive semantics, lexical semantics, discourse analysis, sociolinguistics.

Correspondence: o.zaluzhna@donnu.edu.ua

Oleksandra Kholodiuk is a student of English Philology Department at Vasyl' Stus Donetsk National University, Vinnytsia, Ukraine. Her areas of research include discourse analysis, semantic syntax, linguistic pragmatics.

Correspondence: kholodiuk.o@donnu.edu.ua

Надійшла до редакції 16 вересня 2020 року Рекомендована до друку 15 жовтня 2020 року 